\section{Night Interruption Lighting Is Beneficial in the Production of Plugs of Dahlia 'Sunny Rose'}

\author{
Garry Legnani ${ }^{1,3}$ and William B. Miller ${ }^{2,3}$ \\ Department of Horticulture, Clemson University, Clemson, SC 19624
}

Additional index words. geophyte, herbaceous perennial, tuberization, Dahlia sp., photoperiod

\begin{abstract}
Experiments were conducted to evaluate effects of photoperiod on growth and dry-weight partitioning in Dahlia sp. 'Sunny Rose' during both seedling (plug) production and subsequent production in 10-cm pots. Plugs were grown under short days [9-hour natural photosynthetic photon flux $(P P F)]$ or long days (same 9-hour PPF plus a 4-hour night interruption with incandescent light). Total plant dry weight was unaffected by photoperiod; however, long days (LD) inhibited tuberous root development and increased shoot dry weight, fibrous root dry weight, leaf area, shoot length, and number of leaf pairs. Long days reduced plug production time by $\approx 1$ week compared with short days (SD). Following transplanting to 10 -cm pots, shoot growth and foliar development were superior under LD. There was no effect of photoperiod on foliar $\mathbf{N}$ concentration. The superior growth of LD plugs following transplanting can be attributed to the plant being in a physiological state conducive to shoot expansion instead of storage.
\end{abstract}

Photoperiod affects tuberous root development and floral induction in dahlia. Zimmerman and Hitchcock (1929) reported that Dahlia variabilis Willd. cv. New Jersey grown from rooted leaf cuttings produced larger storage roots when grown under short days (SD) ( 7 or $9 \mathrm{~h}$ ) than did plants grown under natural long days (LD) from June to August. Plants grown under natural photoperiods had more fibrous roots and greater shoot growth and flowered later than those grown under SD. Aoba et al. (1960) observed that dahlia seedlings grown under 8-h photoperiods for $\approx 6$ weeks produced roots with increased diameter compared with seedlings grown under a continuous 24-h photoperiod. Moser and Hess (1969) determined that the critical daylength for tuberous root development in Dahlia variabilis cv. Sneezy was 11 to $12 \mathrm{~h}$. Five inductive cycles were required to induce tuberization in rooted leaf cuttings. Night interruptions inhibited tuberization and were most effective if administered in the middle of the dark period. Further, night temperatures between 15 and $21^{\circ} \mathrm{C}$ were optimal for tuberization, and temperatures below $10^{\circ} \mathrm{C}$ or

Received for publication 10 May 1999. Accepted for publication 28 Mar. 2000. Use of trade names does not imply endorsement of the products named nor criticism of similar ones not named. This research was supported by the Clemson Univ. Ornamental Horticulture Competitive Grants Program. We gratefully acknowledge seed donations from Ball Seed Co., Chicago. The cost of publishing this paper was defrayed in part by the payment of page charges. Under postal regulations, this paper therefore must be hereby marked advertisement solely to indicate this fact.

${ }^{1}$ Graduate Research Associate.

${ }^{2}$ Professor; to whom reprint requests should be addressed. E-mail address: wbm8@cornell.edu

${ }^{3}$ Current address: Dept. of Floriculture and Ornamental Horticulture, 20 Plant Science Bldg., Cornell Univ., Ithaca, NY 14853-5908. above $27^{\circ} \mathrm{C}$ were inhibitory. Photoperiod had a greater influence on vegetative development than on reproductive development of Dahlia pinnata Cav. 'Royal Dahlietta Yellow' (Brondum and Heins, 1993). Brondum and Heins (1993) observed a large increase in tuberous root weight with decreasing photoperiods (16 to $10 \mathrm{~h})$. Temperature $\left(25\right.$ to $\left.15^{\circ} \mathrm{C}\right)$ interacted with photoperiod, with low temperature favoring tuberous root development.

Seed-propagated dwarf dahlias are primarily grown for use as spring bedding plants, although there is increased interest in producing them as potted plants. In either case, seedling (plug) production generally occurs under the naturally short photoperiods of middle to late winter, and seedlings often produce excessively large tuberous roots that can make manual or automated extraction from the plug tray difficult. We hypothesized that LD during plug production would inhibit tuberous root formation and reduce production time by allocating more photosynthate into aerial biomass, rather than tuberous roots. Such plants may also show superior fibrous root development and greater nutrient uptake. The objectives of this study were to: 1) compare the effects of LD (night interruption lighting) and SD on the growth and development of Dahlia sp. 'Sunny Rose' seedlings (plugs); and 2) evaluate vegetative growth following transplanting to $10-\mathrm{cm}$ pots.

\section{Materials and Methods}

Expt. 1. Plant culture. Dahlia sp. 'Sunny Rose' seeds (Ball Seed Co., West Chicago, Ill.) were sown $7 \mathrm{Feb}$. (two seeds per cell) in plug trays containing eighty 2.5 -cm-deep cells filled with Fafard Superfine Germinating Mix (Fafard, Anderson, S.C.). The flats were misted, covered with clear plastic wrap, and placed in a growth chamber with 24-h fluorescent light- ing at $18^{\circ} \mathrm{C}$. Germination occurred in $\approx 4$ to 5 $\mathrm{d}$, after which the plastic wrap was removed. Seven days after sowing, flats were thinned to one seedling per cell and moved to a glass greenhouse (Clemson, S.C.) for photoperiod treatments. Greenhouse night temperatures were maintained at $17^{\circ} \mathrm{C}$, with maximum day temperatures reaching $27^{\circ} \mathrm{C}$. During the second week of production, flats were sub-irrigated and fertilized by immersion in a tray containing $50 \mathrm{mg} \cdot \mathrm{L}^{-1} \mathrm{~N}$ from $20 \mathrm{~N}-4.4 \mathrm{P}-16.6 \mathrm{~K}$ (Grace-Sierra Horticultural Products Co., Milpitas, Calif.). Following the second week of production, as seedlings became established enough for overhead watering, they were fertilized at each watering with the same fertilizer mixture at $150 \mathrm{mg} \cdot \mathrm{L}^{-1} \mathrm{~N}$. Weekly sprays (to runoff) of $33 \mathrm{mg} \cdot \mathrm{L}^{-1}$ ancymidol ( $\alpha$-cyclopropyl, $\alpha$-4-methoxy-propyl, $\alpha$-5-pyrimidine) were applied beginning on $28 \mathrm{Feb}$. for height control.

Photoperiod treatments. On day 7 in the greenhouse, five flats were placed under LD (9-h natural daylight + night interruption lighting) while the other five received SD (9-h natural daylight). All plants received $9 \mathrm{~h}$ of natural photosynthetically active radiation $(P A R)$ from 0900 to $1800 \mathrm{HR}$. Flats in both photoperiod treatments were covered with a black-cloth curtain from 1800 to $0900 \mathrm{HR}$. Plugs in the LD treatment were given a night interruption ( 2200 to $0200 \mathrm{HR}$ ) by two incandescent lamps providing $\approx 2 \mu \mathrm{mol} \cdot \mathrm{m}^{-2} \cdot \mathrm{s}^{-1} P P F$. Plugs in each flat were randomly assigned harvest dates prior to the start of photoperiod treatments. Five seedlings (the experimental unit) were harvested per flat (replication) 2, 4, and 6 weeks following the start of photoperiod treatments.

Harvesting procedures and data collection. All harvests began at 1300 HR. Shoots were cut at the soil surface, and shoot length, number of leaves, shoot fresh weight, and leaf area recorded. Roots were harvested at 1500 HR. Tissues were rinsed with tap water, followed by more extensive rinsing with distilled water. Tuberous and fibrous roots were separated and fresh weight recorded. All tissues were freeze-dried and dry weight of shoots and roots (fibrous and tuberous) recorded.

Expt. 2. Plugs were grown under LD or SD for 6 weeks as described above. On 31 Mar., $30 \mathrm{LD}$ and $30 \mathrm{SD}$ plugs were transplanted to 10 -cm pots and grown under natural daylengths in a completely randomized design. Plants were fertilized at each watering with the same fertilizer mixture used in Expt. 1 at a 200 $\mathrm{mg} \cdot \mathrm{L}^{-1} \mathrm{~N}$ concentration. Two, 4 , and 6 weeks following transplanting, six plants (replications) from each treatment were randomly harvested. Shoot lengths were recorded (rim of pot to top of plant). Shoots were removed at the soil surface and fresh weights (including flowers) determined. Leaves were removed, frozen in liquid nitrogen, freeze-dried, and ground. For $\mathrm{N}$ determination, leaf tissues were digested by the method of Parkinson and Allen (1975) and the amount of $\mathrm{NH}_{4}{ }^{+}$was determined by a colorimetric procedure described by Baethgen and Alley (1989).

Statistical analyses. Analysis of variance (ANOVA) and mean separation within weeks 
using Method of Least Squares Means was conducted using SAS (SAS Institute, Cary, N.C.).

\section{Results and Discussion}

Expt. 1. Although photoperiod treatments had no effect on total plant dry weight, photoperiod altered photosynthate partitioning between roots and shoots, with SD increasing tuberous root development at the expense of shoot growth (Table 1). These differences in dry weight of shoots and roots were first observed at week 4 (Table 1). By week 6, LD plugs showed a $63 \%$ increase in shoot dry weight over SD plugs, but the dry weight of their tuberous roots was less than half that of SD plugs.

No visible macroscopic evidence of tuberous root formation was discernible at week 2 . By week 4 there was noticeable swelling at the stem bases on both LD and SD plugs, although this swelling was greater on the SD plugs. Adventitious tuberous roots originated from the swollen base of the stems independently of fibrous roots and were greater in diameter than the latter. These tuberous roots were noticeably larger on SD than on LD plugs. At week 6 , SD plugs had developed large, rounded, tuberous roots while LD plugs had produced slender, elongated structures. Tuberous root dry weight was 2.4-fold as great in SD as in LD plugs at week 6 . In contrast, LD plugs had a more extensive fibrous root system; dry weight of the fibrous roots was 2-fold as great in LD as in SD plugs (Table 1).

Tuberous root development in dahlia plugs is likely influenced by growth-retardant applications. Moser and Hess (1969) showed that exogenous applications of gibberellic acid (GA) inhibited tuberous root formation in Dahlia pinnata while applications of daminozide (succinic acid-2,2 dimethyl-hydrazide), an inhibitor of GA synthesis, promoted tuberization. Read et al. (1972) found that foliar applications of daminozide caused tuberous root formation in dahlia under LD conditions, while nontreated plants produced only fibrous roots. Although the applications of GA and GA inhibitors influence tuberous root development, they cannot act as a substitute for the effects of photoperiod (Biran et al., 1972; Moser and Hess, 1969). Interactions between photoperiod and growth regulator applications in dahlia plug production warrant further study.

Week 4 plants had greater leaf area under LD than under SD without a substantial increase in the average number of leaf pairs. At week 6 , LD plugs showed a $55 \%$ increase in leaf area over SD plugs and had about one more pair of leaves (Table 2). Leaf number may affect the time when the plug is capable of becoming reproductive and thus the time to flower. Barrett and De Hertogh (1978) found that nonpinched, tuberous-rooted cultivars Miramar and Park Princess became reproductive following the unfolding of four to six trueleaf pairs under inductive photoperiods.

Shoots were longer under LD than under SD at week 2 (Table 2). Exposure to far-red

Table 1. Effects of photoperiod on dry weight of roots and shoots of Dahlia sp. 'Sunny Rose' plugs following 2,4 , and 6 weeks of photoperiod treatment. $\mathrm{SD}=9$-h natural irradiance; $\mathrm{LD}=$ identical $P P F$ with a 4$\mathrm{h}$ night interruption with incandescent lighting. Expt. 1.

\begin{tabular}{|c|c|c|c|c|c|c|}
\hline \multirow[b]{2}{*}{ Week } & \multirow[b]{2}{*}{ Photoperiod } & \multicolumn{5}{|c|}{ Dry wt (g) of: } \\
\hline & & Shoot & Root & $\begin{array}{c}\text { Tuberous } \\
\text { root }\end{array}$ & $\begin{array}{c}\text { Fibrous } \\
\text { root }\end{array}$ & $\begin{array}{l}\text { Total } \\
\text { plant }\end{array}$ \\
\hline \multirow[t]{2}{*}{2} & LD & 0.11 & 0.04 & 0.00 & 0.04 & 0.15 \\
\hline & SD & $0.10^{\mathrm{Ns}, \mathrm{z}}$ & $0.04^{\mathrm{Ns}}$ & $0.00^{\mathrm{ss}}$ & $0.04^{\mathrm{Ns}}$ & $0.14^{\mathrm{Ns}}$ \\
\hline \multirow[t]{2}{*}{4} & LD & 0.51 & 0.17 & 0.06 & 0.11 & 0.68 \\
\hline & SD & $0.41^{\mathrm{Ns}}$ & $0.24^{*}$ & $0.17^{*}$ & $0.07^{*}$ & $0.65^{\mathrm{Ns}}$ \\
\hline \multirow[t]{2}{*}{6} & LD & 1.02 & 0.45 & 0.28 & 0.18 & 1.46 \\
\hline & SD & $0.59^{* * * *}$ & $0.76^{* * * *}$ & $0.67^{* * * *}$ & $0.09^{* * *}$ & $1.35^{\mathrm{Ns}}$ \\
\hline \multicolumn{7}{|c|}{ Significance } \\
\hline \multirow{2}{*}{\multicolumn{2}{|c|}{$\begin{array}{l}\text { Week }(\mathrm{W}) \\
\text { Photoperiod }(\mathrm{P})\end{array}$}} & $* * *$ & $* * *$ & $* * *$ & $* * *$ & $* * *$ \\
\hline & & $* * *$ & $*$ & $* *$ & $*$ & NS \\
\hline \multicolumn{2}{|c|}{$\mathrm{W} \times \mathrm{P}$} & $* * *$ & ** & $* * *$ & $* *$ & NS \\
\hline
\end{tabular}

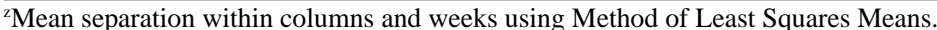

ss, ${ }^{* * *, * * *}$ Nonsignificant or significant at $P \leq 0.05,0.01$, or 0.001 , respectively $(\mathrm{n}=5)$.

Table 2. Effects of photoperiod on leaf area, shoot length, and number of leaf pairs in Dahlia sp. 'Sunny Rose' plugs following 2, 4, and 6 weeks of photoperiod treatment. $\mathrm{SD}=9$-h natural irradiance; $\mathrm{LD}=$ identical $P P F$ with a 4-h night interruption with incandescent lighting. Expt. 1.

\begin{tabular}{|c|c|c|c|c|}
\hline Week & Photoperiod & Leaf area $\left(\mathrm{cm}^{2}\right)$ & Shoot length $(\mathrm{cm})$ & No. leaf pairs \\
\hline \multirow[t]{2}{*}{2} & LD & 35.5 & 4.1 & 2.0 \\
\hline & SD & $35.6^{\mathrm{Ns}, \mathrm{z}}$ & $3.7^{*}$ & $2.0^{\mathrm{Ns}}$ \\
\hline \multirow[t]{2}{*}{4} & LD & 101.4 & 5.7 & 3.0 \\
\hline & SD & $84.3^{*}$ & $4.8^{* * *}$ & $3.2^{\mathrm{vs}}$ \\
\hline \multirow[t]{2}{*}{6} & LD & 169.0 & 7.2 & 5.2 \\
\hline & SD & $109.4^{* * *}$ & $5.0^{* * *}$ & $4.5^{* * *}$ \\
\hline \multicolumn{5}{|l|}{ Significance } \\
\hline Week (W) & & $* * *$ & $* * *$ & $* * *$ \\
\hline Photoperiod (P) & & $* *$ & $* * *$ & $* *$ \\
\hline $\mathrm{W} \times \mathrm{P}$ & & $* * *$ & $* * *$ & $* * *$ \\
\hline
\end{tabular}

${ }^{\mathrm{z}}$ Mean separation within columns and weeks using Method of Least Squares Means.

Ns, *,****** Nonsignificant or significant at $P \leq 0.05,0.01$, or 0.001 , respectively $(\mathrm{n}=5)$.

Table 3. Effects of photoperiod on growth and development of Dahlia sp. 'Sunny Rose' plugs 2, 4, and 6 weeks following transplanting to $10-\mathrm{cm}$ pots. Following transplanting (31 Mar.) all treatments were placed in a normal daylength environment. $\mathrm{SD}=9$-h natural irradiance, $\mathrm{LD}=$ identical $P P F$ with a 4$\mathrm{h}$ night interruption with incandescent lighting. Expt. 2.

\begin{tabular}{|c|c|c|c|c|c|c|}
\hline $\begin{array}{l}\text { Weeks after } \\
\text { transplant }\end{array}$ & $\begin{array}{c}\text { Plug } \\
\text { photoperiod }\end{array}$ & $\begin{array}{c}\text { Shoot } \\
\text { fresh wt }(\mathrm{g})\end{array}$ & $\begin{array}{c}\text { Shoot } \\
\text { length }(\mathrm{cm})\end{array}$ & $\begin{array}{c}\text { Leaf dry } \\
\text { wt (g) }\end{array}$ & $\begin{array}{c}\text { Foliar } \mathrm{N} \\
\text { concn } \\
\left(\mathrm{mg} \cdot \mathrm{g}^{-1} \text { dry wt) }\right.\end{array}$ & $\begin{array}{c}\text { Foliar N } \\
\text { content } \\
(\mathrm{mg} / \text { shoot })\end{array}$ \\
\hline \multirow[t]{2}{*}{$\overline{2}$} & LD & 9.5 & 12 & 0.9 & 41.3 & 36.3 \\
\hline & SD & $5.7^{\mathrm{Ns}, \mathrm{z}}$ & $8^{* * *}$ & $0.5^{\mathrm{Ns}}$ & $44.5^{\mathrm{Ns}}$ & $20.3^{\mathrm{Ns}}$ \\
\hline \multirow[t]{2}{*}{4} & LD & 48.3 & 20 & 4.7 & 36.6 & 170.0 \\
\hline & SD & $31.1^{\text {***** }}$ & $17^{* *}$ & $2.8^{* * * *}$ & $41.4^{* *}$ & $117.8^{* *}$ \\
\hline \multirow[t]{2}{*}{6} & LD & 95.6 & 27 & 7.9 & 38.7 & 306.4 \\
\hline & SD & $79.5^{* * *}$ & $24^{* *}$ & $6.4^{* * * *}$ & $37.7^{\mathrm{Ns}}$ & $224.4^{* * * *}$ \\
\hline \multicolumn{7}{|l|}{ Significance } \\
\hline \multirow{2}{*}{\multicolumn{2}{|c|}{$\begin{array}{l}\text { Week (W) } \\
\text { Photoperiod (P) }\end{array}$}} & $* * *$ & $* * *$ & $* * *$ & $* * *$ & $* * *$ \\
\hline & & $* * *$ & $* * *$ & $* * *$ & $*$ & $* * *$ \\
\hline \multicolumn{2}{|c|}{$\mathrm{W} \times \mathrm{P}$} & $*$ & NS & $* *$ & NS & NS \\
\hline
\end{tabular}

${ }^{\mathrm{z}}$ Mean separation within columns and weeks using Method of Least Squares Means.

Ns, $, * * *, * * *$ Nonsignificant or significant at $P \leq 0.05,0.01$, or 0.001 , respectively $(\mathrm{n}=6)$.

light increases stem elongation (Smith, 1982). Long-day plugs continued to grow taller while growth in height of SD plugs ceased at week 4. By week 6, LD plugs were $50 \%$ taller than SD plugs. We suspect that this increase was attributable to both increased partitioning to the shoot and increased exposure to far-red light during the night interruption.

In summary, LD promoted shoot growth, foliar development, and fibrous root growth in plugs, but reduced growth of tuberous roots. Long-day plugs were of salable size and quality at week 5 , but SD plugs were not salable until week 6 .

Expt. 2. Following transplanting to $10-\mathrm{cm}$ pots and growing-on in natural photoperiods (April-May), plugs from each photoperiod treatment grew rapidly; however, shoot fresh weight, leaf dry weight, and shoot length were greater in LD plugs (Table 3). All plants were flowering at the week 6 harvest. Plants grown from LD plugs had better overall foliage development. Plugs grown under SD had slightly greater leaf $\mathrm{N}$ concentration 2 and 4 weeks posttransplant, but there was no difference by week 6 . When calculated on a leaf content basis (i.e., mg total leaf $\mathrm{N}$ per plug), LD plugs had more leaf $\mathrm{N}$ than did SD plugs (Table 3), but this was due entirely to greater leaf weight. These results suggest that despite their greater 
fibrous root development, increased $\mathrm{N}$ uptake is not a contributing factor to the accelerated growth of LD plugs following transplanting. A preliminary study investigating flowering characteristics of LD and SD plugs has been conducted and will be the focus of future research in this area.

The benefits of lighting with incandescent lamps during dahlia plug production include: smaller tuberous roots; increased shoot growth, fibrous root production, and leaf area; and shorter production time. One possible drawback is increased "stretching" of LD plugs, which may be alleviated by the use of fluorescent lighting (rather than the incandescent lamps we used), or by using plant growth retardants. "Stretching" should not be an issue unless plugs are left to grow under LD for several weeks beyond the salable stage. Our results also show that plugs grown under LD grow faster and have better foliage development than do plugs grown under SD following repotting. The increased growth of LD plugs following transplanting can be attributed to the plant being in a physiological state that promotes the partitioning of assimilates to shoot growth instead of storage organ development.

\section{Literature Cited}

Aoba, T., S. Wantanabe, and C. Saito. 1960. Studies on tuberous root formation in dahlia. I. Periods of tuberous root formation in dahlia. J. Jpn. Soc. Hort. Sci. 29:247-252.

Baethgen, W.E. and M.M. Alley. 1989. A manual colorimetric procedure for measuring ammonium nitrogen in soil and plant Kjeldahl digests. Comm. Soil Sci. Plant Anal. 20:961-969.

Barrett, J.E. and A.A. De Hertogh. 1978. Comparative inflorescence development of two cultivars of forced tuberous-rooted dahlias. J. Amer. Soc. Hort. Sci. 103:767-772.

Biran, I., I. Gur, and A.H. Halevy. 1972. The relationship between exogenous growth inhibitors and endogenous levels of ethylene, and tuberization of dahlias. Physiol. Plant. 27:226230.

Brondum, J.J. and R.D. Heins. 1993. Modeling temperature and photoperiod effects on growth and development of dahlia. J. Amer. Soc. Hort. Sci. 118:36-42.

Moser, B.C. and C.E. Hess. 1968. The physiology of tuberous root development in dahlia. Proc. Amer. Soc. Hort. Sci. 93:595-603.

Parkinson, J.A. and S.E. Allen. 1975. A wet oxidation procedure suitable for the determination of nitrogen and mineral nutrients in biological material. Comm. Soil Sci. Plant Anal. 6:1-11.

Read, P.E., C.W. Dunham, and D.J. Fieldhouse 1972. Increasing tuberous root production in Dahlia pinnata Cav. with SADH and chlormequat. HortScience 7:62-63.

Smith, H. 1982. Light quality, photoperception, and plant strategy. Annu. Rev. Plant Physiol. 33:481518.

Zimmerman, P.W. and A.E. Hitchcock. 1929. Root formation and flowering of dahlia cuttings when subjected to different day lengths. Bot. Gaz. 87:1-13. 